\title{
Eyelid Carcinoma pT4 TNM Finding v8
}

National Cancer Institute

\section{Source}

National Cancer Institute. Eyelid Carcinoma pT4 TNM Finding v8. NCI Thesaurus. Code C140501.

Any eyelid carcinoma invading adjacent ocular, orbital, or facial structures. (from AJCC 8th Ed.) 